\title{
Prevention of Epidural Fibrosis Using Ranibizumab in a Postlaminectomy Rat Model
}

\author{
Ali YILMAZ1', Mete KARATAY², Timur YILDIRIM', Haydar CELIK², Idris SERTBAS², Yavuz ERDEM², \\ Muzaffer CAYDERE ${ }^{3}$, Hasan Serdar ISIK ${ }^{1}$, Mehmet Akif BAYAR ${ }^{2}$
}

${ }^{1}$ Ordu University, School of Medicine, Department of Neurosurgery, Ordu, Turkey

${ }^{2}$ Ankara Training and Research Hospital, Department of Neurosurgery, Ankara, Turkey

${ }^{3}$ Ankara Training and Research Hospital, Department of Pathology, Ankara, Turkey

\section{ABSTRACT}

AIM: One of the most significant reasons for persistent low back pain experienced after spinal surgery is epidural fibrosis seen after laminectomy procedures. This study shows the effects of Ranibizumab on spinal epidural fibrosis in the laminectomy area by blocking the effect of vascular endothelial growth factor.

MATERIAL and METHODS: Twenty Wistar rats were used in this study. Rats were divided into two groups; a control group and a ranibizumab group. Only laminectomy was performed to the control group. In the ranibizumab group, $0.6 \mathrm{mg} / \mathrm{kg}$ ranibizumab diluted in $0.9 \% \mathrm{NaCl}$ with the ratio of 1:10 was applied topically. Three weeks later, the vertebral columns were resected en bloc including the whole laminectomy area in both groups and evaluated histopathologically. Results were compared using statistical tools.

RESULTS: Based on the statistical analysis, our data show that less epidural fibrosis was seen in the ranibizumab group compared to the control group $(\mathrm{P}<0.05)$.

CONCLUSION: Topically applied Ranibizumab is significantly effective in preventing epidural fibrosis in rats occurred after laminectomy.

KEYWORDS: Epidural fibrosis, Laminectomy, Ranibizumab

\section{INTRODUCTION}

$\mathrm{I}$ $t$ is currently known that one of the most significant reasons for persistent low back pain experienced after spinal surgery is epidural fibrosis seen after laminectomy procedures $(2,17,18,28,34,35,37)$. Epidural fibrosis is a natural process of laminectomy performed during surgery (17).

According to studies in the United States, laminectomy and laminotomy are performed on approximately 250000 people per year because of lumbar disc herniation. 30000-40000 of these result in failed back surgery $(6,12,13)$. If we consider the additional laminotomies and laminectomies performed for many reasons such as spinal trauma, spinal stenosis, scoliosis, tumor etc., we can appreciate that many patients face the risk of epidural fibrosis. The rate of persistent low back pain due to epidural fibrosis seen post laminotomy and laminectomy is $1-40 \%$. Previous studies have shown that fibrotic tissue causing pressure on surrounding anatomic structures lead to clinical sequelae $(17,18,27)$.

Many methods and agents have been used to prevent the development of epidural fibrosis so far; however, none of them has been widely accepted in routine clinical practice (26).

Ranibizumab, which has the effect of Anti-Vascular Endothelial Growth Factor (VEGF) that is used in macular degeneration of the eye, has been shown to decrease new vascular formation in the scar tissue by inhibiting the effect of VEGF (44). 
Table I: Scoring of the Scar Amount (20)

\begin{tabular}{ll}
\hline Grade 0 & No scar tissue adhered to dura. \\
\hline Grade I & Only a thin fibrous band between the scar tissue and dura. \\
\hline Grade II & Ongoing adhesion is observed but it composes less than $2 / 3$ of the laminectomy defect \\
\hline Grade III & $\begin{array}{l}\text { Scar tissue adhesion is larger or composing more than } 2 / 3 \text { of the laminectomy defect and/or extending to the } \\
\text { nerve root }\end{array}$ \\
\hline
\end{tabular}

Table II: Histological Results of Epidural Fibrosis Grades

\begin{tabular}{lcc}
\hline Epidural Fibrosis Grade & $\begin{array}{c}\text { Control } \\
\text { Group }\end{array}$ & $\begin{array}{c}\text { Ranibizumab } \\
\text { Group }\end{array}$ \\
\hline Grade 0 & 0 & 1 \\
\hline Grade I & 0 & 4 \\
\hline Grade II & 4 & 3 \\
\hline Grade III & 6 & 2 \\
\hline
\end{tabular}

In this study, we analyzed whether ranibizumab had an inhibitory effect on the development of epidural fibrosis, which develops as a natural result of laminectomy, in the epidural fibrosis model developed in post laminectomy rats.

\section{- MATERIAL and METHODS}

This study was conducted at the Experimental Animals Research Laboratory of the Ankara Teaching and Research Hospital, upon the approval of the Animal Experimentation Local Board of Ethics of Ankara Teaching and Research Hospital dated 08/10/2013-227.

In our study, 20 male Wistar rats aged between 8-12 months with an average weight of $200-250 \mathrm{gr}$ were used. The rats were categorized into 2 groups. A single dose of $50 \mathrm{mg} /$ $\mathrm{kg}$ of ceftriaxone (Rocephin, Roche, Turkey) was given intraperitoneally to the rats 30 minutes before surgery for prophylactic reasons. Anesthesia was induced by intramuscular ketamine hydrochloride $(25 \mathrm{mg} / \mathrm{kg}$; Ketalar, Pfizer, Istanbul, Turkey) and Xylazine (5 mg/kg; Rompun, Bayer, Istanbul, Turkey). The rats were fixed to the operating table in prone position. After the fixation, the operation site was brushed with povidone iodine scrub (Medicabrush; 4\% chlorhexidine soap, Medica BV, Netherlands) for 10 minutes and disinfected with povidone-iodine (Poviod; $10 \%$ polyvinylpyrrolidoneiodine complex, Saba, Turkey) solution. The surgical site was covered with sterile covers. By means of a median skin incision the L1-S1 vertebrae were spaced. Paravertebral muscles were stripped by microdissection. Total laminectomy was performed on L3, L4, L5 vertebrae. Ligamantum flavum and epidural fat tissue were cleaned. Lumbar epidural space was exposed by bipolar after hemostasis. No dural tear and injury in the nerve root was observed during the procedure in any of the rats. The $1^{\text {st }}$ group of the rats had laminectomy only. The $2^{\text {nd }}$ group received $0.6 \mathrm{mg} / \mathrm{kg}$ of ranibizumab (Lucentis ${ }^{\circledR}$, Roche), which was diluted by $1 / 10$ with $0.9 \%$ of $\mathrm{NaCl}$ and applied topically on the epidural space with cotton for 5 minutes. The soaked cotton was removed from the surgical site after 5 minutes and the layers were closed in the anatomical plane. All the surgical procedures were performed with 16 times magnification by the OpMi (Carl Zeiss, Germany) microscope. None of the subjects had infection. The rats were sacrificed after 3 weeks with intraperitoneal high dose of $75-100 \mathrm{mg} /$ kg sodium thiopental (Pentothalsodium, Abbott, Italy). The vertebral column was removed including the laminectomy site. The material was fixed with $10 \%$ of formal ( $4 \%$ formaldehyde). They were decalcified with $30 \%$ formic acid for 2 days. Serial sections were collected from each block for histopathological analysis. They were stained with hematoxylin eosin (HE). The preparations were examined under light microscope. Photos of the scar tissue were taken using the Zeisslmager M2" microscope. Staging of the epidural scar tissue was done according to plan described by He et al. (20) (Table I).

\section{Statistical Analysis}

Data analysis was performed by using SPSS for Windows, version 11.5 (SPSS Inc., Chicago, IL, United States). The differences between control and Ranibizumab groups regarding epidural fibrosis grade were evaluated by the MannWhitney $U$ test. A $p$ value less than 0.05 was considered statistically significant.

\section{RESULTS}

In our study, no dura nerve injury or infection was defined in any of the subjects. Epidural fibrosis development was found to be significantly lower in ranibizumab group compared to the control group $(p=0.016)$ (Figure 1). Grade II epidural fibrosis was defined in 4 rats and grade III was defined in 6 rats in the control group (Figure 2). In the ranibizumab group, grade 0 epidural fibrosis was defined in 1 rat (Figure 3 ), grade $I$ in 4 rats, grade II in 3 rats and 2 rats had grade III epidural fibrosis (Table II).

\section{DISCUSSION}

Epidural fibrosis is seen as a natural consequence of laminotomy and laminectomy performed due to many reasons $(3,20)$. Failed Back Surgery Syndrome (FBSS), in other words post laminectomy syndrome, composes a subgroup of chronic low back pain. It covers the group of patients with persistent low back and leg pain after spinal laminectomy and laminotomy (16). One of the most important reasons of FBSS is the development of epidural fibrosis after laminectomy and laminotomy $(4,19,23,38,41)$. 


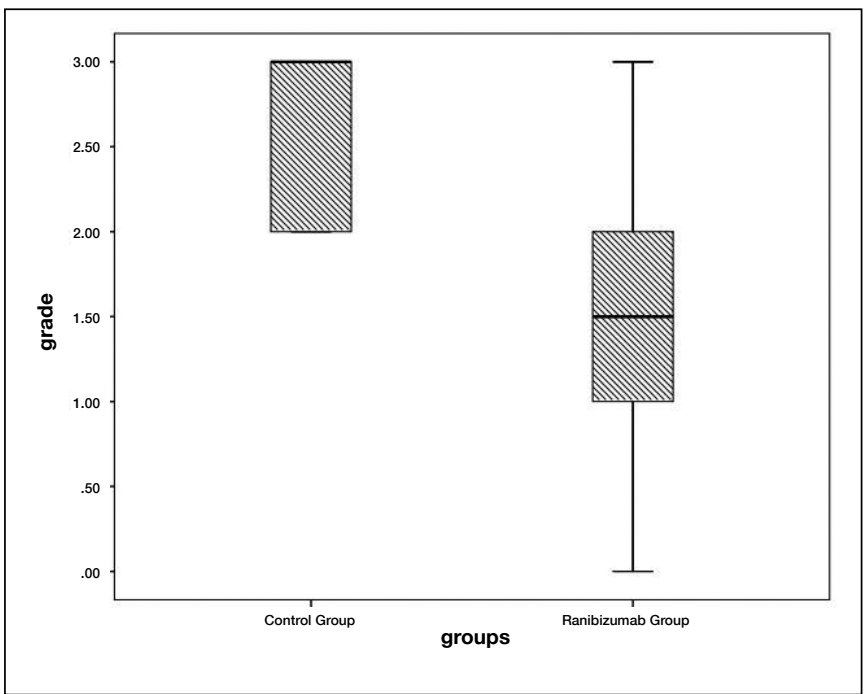

Figure 1: Epidural fibrosis grades shown with box plot. The ranibizumab group had a significantly lower epidural fibrosis grade $(p=0.03)$.

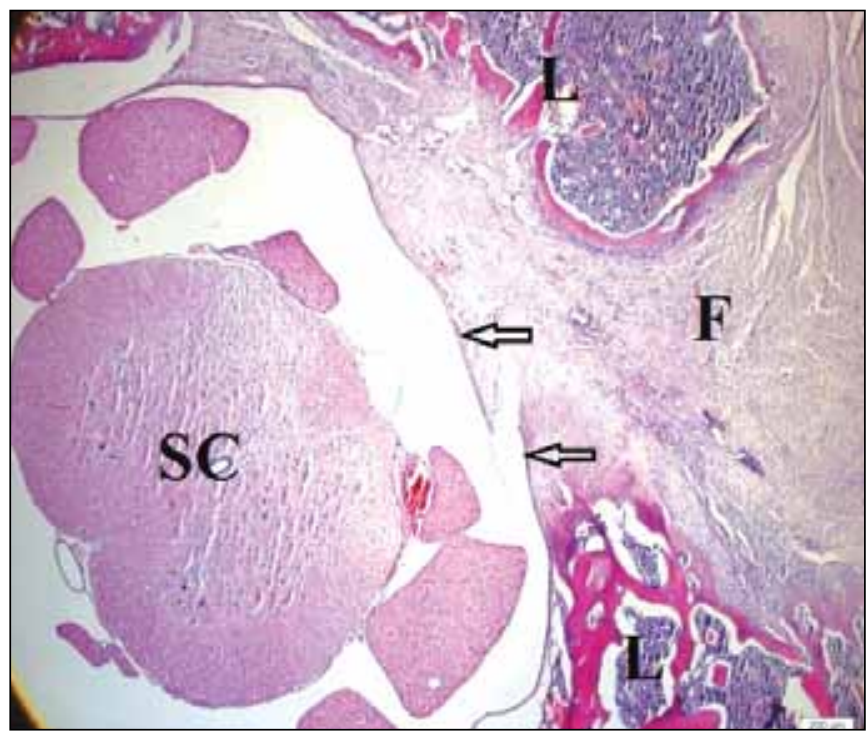

Figure 2: Microscopic image shows Grade III fibrosis as observed in the control group. The epidural fibrosis adhered to the underlying dura mater. $\mathbf{L}=$ lamina; $\mathbf{F}=$ fibrosis; $\mathbf{S C}=$ spinal cord; Black arrows $=$ dura mater. Scale bar $=200 \mu \mathrm{m}$.

Epidural fibrosis develops with the combination of fibroblasts and elements including inflammatory cells and collagen produced by fibroblasts. As a result of adhesions stemming from epidural fibrosis formation, a pressure and tension effect is seen on the spinal cord and nerves $(4,19,38)$. This adhesion may disrupt the arterial supply, venous drainage and axoplasmic transport in the nerve fibers. Although there is no consensus about the mechanism of the scar tissue in the etiology of the pain, it is reported that the adhesions cause pressure on the surrounding anatomical structures and increase the sensitivity of the nerve tissue in addition to the limitation of mobility in the nerve root $(10,18,30,45)$.

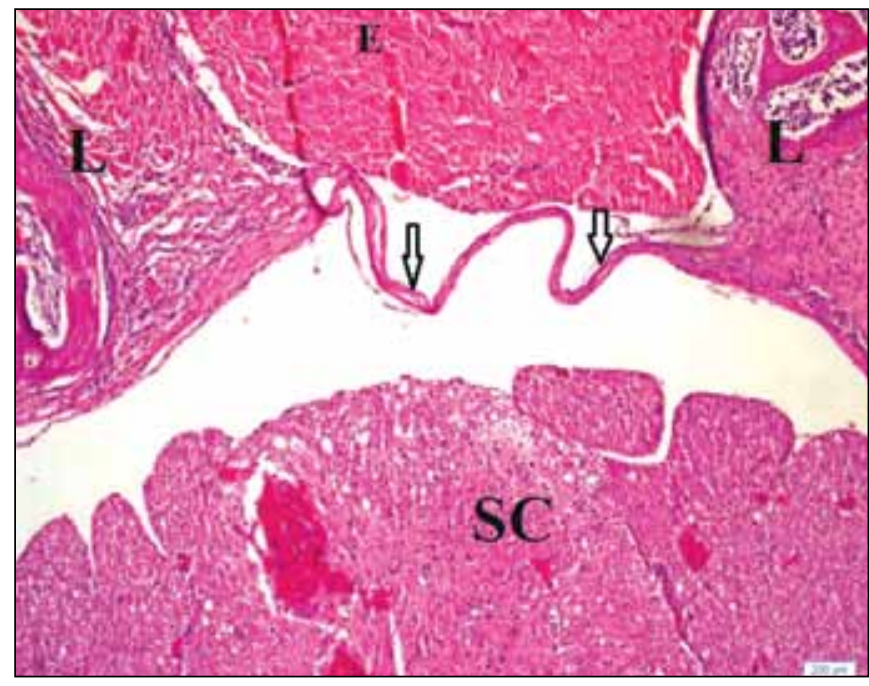

Figure 3: Microscopic image shows Grade 0 fibrosis as observed in the ranibizumab group. The dura mater was free of scar tissue E: epidural area (No scar tissue adhered to dura), $\mathbf{S C}=$ spinal cord; L= lamina; Black arrows= dura mater. Scale bar $=200 \mu \mathrm{m}$.

Today, the pathophysiological process of epidural fibrosis formation is still under debate. Many factors are set forth in clinical and animal studies. Such factors as individual variations in scar tissue and its formation, postoperative hematoma, laminectomy technique and amount of bone removed in laminectomy are blamed (34). It is shown that fibroblast migration into the surgical field plays a key role in the formation of epidural fibrosis (26). Fibroblasts originate from paravertebral muscles and are transported to the surgical site with blood causing strong adhesions in the tissue (26).

There is an increase in vascular permeability during wound healing and in the early period of repair (9). This event allows the storage of fibrin rich extracellular matrix proteins for cell migration and proliferation (34).

Together with the post-spinal surgery epidural fibrosis, low back pain is experienced due to sciatic irritation (22). Many studies have been conducted so far in order to decrease epidural fibrosis. Numerous methods such as Silastic-Dacron gelatin sponge, animal collagen membranes, Adcon-L, autologous lipid graft, local cortisone application, tenoxicam application, omental graft, and bevacizumab 5-Fluorouracil combination have been tried. However, they are not totally used in routine practice $(8,11,14,25,29,36)$.

VEGF is a strong angiogenic cytokine that includes several sub-groups named VEGF-A, VEGF-B, VEGF-C, VEGF-D and VEGF-E. It has been proven that VEGF protects the endothelial cells from radiation and stress-induced apoptosis, ensures the survival of cancer cells (43) and is actively effective in cell regeneration, fibroblast function, wound healing, and reaction to inflammation (21). VEGF plays a role in the formation of adhesions and helps the vascularization process in the postoperative damaged area (24). 
Today, it is known that VEGF production is stimulated by some environmental factors, growth factors, oncogenes, cytokines and hormones. The VEGF that is produced is bound to the endothelial cell surface and intracellular tyrosine kinase is activated. VEGF-A is the form that is primarily responsible for angiogenesis and vascular permeability. VEGF-A has 9 isoforms according to the number of amino acids $(1,33)$. AntiVEGF treatment regimens are based on this basic information. The studies show that the anti-VEGF agents prevent tissue adhesions that are formed secondary to these events by decreasing endothelial cell angiogenesis and vascular permeability (24).

Ranibizumab (Lucentis ${ }^{\circledR}$, Novartis) is a molecule containing the antigen-binding fragment of the anti-VEGF antibody that is produced by recombinant DNA technology (44). It binds to all of the isoforms of VEGF-A and eliminates their effect. Ranibizumab was approved by the FDA for the treatment of choroidal neovascularization in wet age-related macular degeneration (AMD) intravitreally (7). The clinical efficacy and reliability of ranibizumab have been shown in various studies (40). The fact that anti-VEGF agents decrease adhesions by decreasing new vessel formation in damaged tissue by an anti-VEGF feature is well documented in animal studies of the eye, abdominal surgery, and laminotomy models $(5,31)$. Hypertension and renal and cardiac toxicity have been defined in cases as a consequence of the administration of anti-VEGF agents for various reasons. The mechanism is not entirely known (15).

Before the approval of ranibizumab by the FDA in 2006, premise drug bevacizumab, an anti-VEGF agent, was approved by the FDA in 2004 for the treatment of metastatic cancer of the colon or rectum as an intravenous infusion (15). Rosenfeld pioneered the off-label use of bevacizumab in the eye after previous data suggested its efficacy in treatment of wet AMD intravenously $(32,39)$. Bevacizumab is a larger molecule with a longer half-life than ranibizumab. Both ranibizumab and bevacizumab inhibit all biologically active forms of VEGF (46). Although both drugs have been shown independently to be effective in macular degeneration as antiVEGF agents, Subramanian et al. showed in a prospective, randomized, double-masked study that the central macular thickness measured by optical coherence tomography (OCT) was greater in the ranibizumab group compared with the bevacizumab group. There was also a great improvement in central foveal thickness in the ranibizumab group. However, they found no difference in visual and anatomic outcomes at 1 year (42). Today, ranibizumab is the current gold standard as an anti-VEGF in the treatment of AMD in the United States (42).

In addition, in a study conducted with bevacizumab on rat models, epidural fibrosis was reported to decrease. Histopathologic examinations showed that epidural fibrosis was significantly less in the group where bevacizumab was used (24). Further studies can be done to clarify the differences between ranibizumab and bevacizumab on epidural fibrosis.

\section{CONCLUSION}

Our study shows the effects of ranibizumab, an anti-VEGF agent, in preventing epidural fibrosis in post laminectomy rat models. According to the histopathological analysis, we observed that the ranibizumab-administered group had significantly less epidural fibrosis compared to the control group. This agent, which is used on a routine basis for other indications, is investigated for the first time for its efficacy in epidural fibrosis. We believe that further laboratory and clinical studies should be conducted to support our study.

\section{REFERENCES}

1. Aiello LP, Northrup JM, Keyt BA, Takagi H, Iwamoto MA: Hypoxic regulation of vascular endothelial growth factor in retinal cells. Arch Ophthalmol 113(12):1538-1544, 1995

2. Alkalay RN, Kim DH, Urry DW, Xu J, Parker TM, Glazer PA: Prevention of postlaminectomy epidural fibrosis using bioelastic materials. Spine (Phila Pa 1976) 28(15):1659-1965, 2003

3. Barbera J, Gonzales J, Esquerdo J, Broseta J, BarcaiSalorio JL: Prophylaxis of the laminectomy membrane. An experimental study in dogs. J Neurosurg 49(3):419-424, 1978

4. Bartynski W, Petropoulou K: The MR imaging features and clinical correlates in low back pain-related syndromes. Magn Reson Imaging Clin N Am 15(2):137-154, 2007

5. Basbug M, Bulbuller N, Camci C, Ayten R, Aygen E, Ozercan IH, Arikanoglu Z, Akbulut S: The effect of antivascular endothelial growth factor on the development of adhesion formation in laparotomized rats: Experimental study. Gastroenterol Res Pract 21:760-775, 2011

6. Benoist M, Ficat C, Baraf P, Cauchoix J: Postoperative lumbar epiduro-arachnoiditis. Spine 5(5):432-436, 1980

7. Blick SK, Keating GM, Wagstaff AJ: Ranibizumab. Drugs 67(8):1199-1206, 2007

8. Boot DA, Hughes SPF: The prevention of adhesions after laminectomy. Adverse results of Zenoderm implantations into laminectomy sites in rabbits. Clin Orthop Relat Res 215: 296302, 1987

9. Breuing K, Erikkson E, Liu P, Miller DR: Healing of partial thickness porcine skin wounds in a liquid environment. J Surg Res 52(1): 50-58, 1992

10. Brodsky AE: Post-laminectomy and post-fusion stenosis of the lumbar spine. Clin Orthop Relat Res 115:130-138, 1976

11. Bryant MS, Bremer AM, Nguyen TQ: Autogenic fat transplants in the epidural space in routine lumbar spine surgery. Neurosurgery 13(4):367-370, 1983

12. Caldwell $A B$, Chase $C$ : Diagnosis and treatment of personality factors in chronic low back pain. Clin Orthop Relat Res 129:141-149, 1977

13. Caner $\mathrm{H}$, Atalay B: Başarısız bel cerrahisi sendromu, omurilik ve omurga cerrahisi. In: M. Zileli, Fahir Özer (eds), Omurilik ve Omurga Cerrahisi. İzmir: Saray Basım ve Yayıncılık, 2003: 789-795 (In Turkish)

14. Cemil B, Tun K, Kaptanoglu E, Kaymaz F, Cevirgen B, Comert A, Tekdemir I: Use of pimecrolimus to prevent pidural fibrosis in a postlaminectomy rat model. J Neurosurg Spine 11(6):758763, 2009 
15. Denizli N, Demirci R, Duranay M, Yilmaz B: New insight into treatment of diseases of glomerular endothelium. Turk Nephrol Dial Transpl 20(3):220-226, 2011

16. Follett KA, Maves TJ: Management of chronic pain of nonmalignant origin. In: Grossman RG, Loftus CM (eds), Principles of Neurosurgery. 2nd ed. Philadelphia, CN: Lippincott-Raven Publishers, 1999: 421-434

17. Geisler FH: Prevention of peridural fibrosis: Current methodologies. Neurol Res 21 Suppl 1:S9-22, 1999

18. Gerszten PC, Moossy JJ, Flickinger JC, Gerszten K, Kalend A, Martinez AJ: Inhibition of peridural fibrosis after laminectomy using low-dose external beam radiation in a dog model. Neurosurgery 46(6): 1478-1484, 2000

19. Gill GG, Scheck M, Kelley ET: Pedicle fat grafts for the prevention of scar in low-back surgery: A preliminary report on the first 92 cases. Spine 10: 662-667, 1985

20. He Y, Revel M, Loty B: A quantitative model of postlaminectomy scar formation. Effects of a nonsteroidal anti-inflammatory drug. Spine 20(5):557-563, 1995

21. Howdieshell TR, Callaway D, Webb WL, Gaines MD, Procter CD Jr, Sathyanarayana, Pollock JS, Brock TL, McNeil PL: Antibody neutralization of vascular endothelial growth factor inhibits wound granulation tissue formation. J Surg Res 96(2): 173-182, 2001

22. Hsei V, Deguzman GG, Nixon A, Gaudreault J: Complexation of VEGF with bevacizumab decreases VEGF clearance in rats. Pharm Res 19(11):1753-1756, 2002

23. Karaman H, Oztürkmen HA, Türkoglu S: Broken racz catheter during application. Ağrı 18(1):33-36, 2006 (In Turkish)

24. Karatay M, Erdem Y, Koktekir E, Erkoc YS, Caydere M, Bayar MA: The effect of bevacizumab on spinal epidural fibrosis in a postlaminectomy rat model. Turk Neurosurg 22(6):753-757, 2012

25. Karatay M, Celik H, Koktekir E, Karatay E, Sertbas I, YıImaz A, Caydere $\mathrm{M}$, Karabaglı $\mathrm{H}$ : Role of tenoxicam in the prevention of postlaminectomy peridural fibrosis in rats. $\mathrm{J}$ Neurol Sci 30(3): 559-565, 2013

26. Kasimcan MO, Bakar B, Aktaş S, Alhan A, Yilmaz M: Effectiveness of the biophysical barriers on the peridural fibrosis of a postlaminectomy rat model: An experimental research. Injury 42(8):778-781, 2011

27. Kathleen ER, Robertson JT, Espinoza T, Cortese S, di Zerega GS, Berg RA: Reduction of epidural fibrosis in lumbar surgery with Oxiplex adhesion barriers of carboxymethylcellulose and polyethylene oxide. Spine J 3(4):277-283, 2003

28. Kelsey JL, White AA 3rd: Epidemiology and impact of lowback pain. Spine 5(2):133-142, 1980

29. MacMillan M, Stauffer ES: The effect of omental pedicle graft transfer on spinal microcirculation and laminectomy membrane formation. Spine (Phila Pa 1976) 16(2):176-180, 1991

30. Martin-Ferrer S: Failure of autologous fat grafts to prevent postoperative epidural fibrosis in surgery of the lumbar spine. Neurosurgery 24: 718-721, 1989

31. Mello GR, Pizzolatti ML, Wasilewski D, Santhiago MR, Budel $\mathrm{V}$, Moreira $\mathrm{H}$ : The effect of subconjunctival bevacizumab on corneal neovascularization, inflammation and re-epithelization in a rabbit model. Clinics (SaoPaulo) 66(8):1443-1450, 2011
32. Moshfeghi AA, Rosenfeld PJ, Puliafito CA, Michels S, Marcus EN, Lenchus JD, Venkatraman AS: Systemic bevacizumab (Avastin) therapy for neovascular age-related macular degeneration: Twenty-four-week result of an uncontrolled open-label clinical study. Ophthalmology 113(11):2002.e1-12, 2006

33. Otani A, Takagi $H$, Oh $H$, Koyama S, Ogura $Y$, Matumura M, Honda YI: Vascular endothelial growth factor family and receptor expression in human choroidal neovascular membranes. Microvasc Res 64:162-169, 2002

34. Ozkan U, Osun A, Samancioglu A, Ercan S, Firat U, Kemaloglu $S$ : The effect of bevacizumab and 5-Fluorouracil combination on epidural fibrosis in a rat laminectomy model. Eur Rev Med Pharmacol Sci 18(1):95-100, 2014

35. Özgen S, Naderi S, Ozek MM, Pamir MN: Finding and outcome of revision lumbar disc surgery. J Spinal Disord 12: 287-292,1999

36. Petrie JL, Ross JS: Use of Adcon-L to inhibit postoperative peridural fibrosis and related symptoms following lumbar disc surgery: A preliminary report. Eur Spine J 5 Suppl 1:S10-17, 1996

37. Pope MH, Costanza MC, Rosen JC, Goggin JE, Wilder DG: Epidemiologic studies of low-back pain. Frymoyer JW Spine 5(5):419-423, 1980

38. Robertson JT: Role of peridural fibrosis in the failed back: A review. Eur Spine J 5(1):S2-6, 1996

39. Rosenfeld PJ: Intravitreal Avastin: The low cost alternative to Lucentis? Am J Ophthalmol 142:141-143, 2006

40. Rosenfeld PJ, Brown DM, Heier JS, Boyer DS, Kaiser PK, Chung CY, Kim RY; MARINA Study Group: Ranibizumab for neovascular age-related macular degeneration. $\mathrm{N}$ Engl J Med 355:1419-1431, 2006

41. Sizer PS, Phelps V, Dedrick G, Matthijs O: Differential diagnosis and management of spinal nerve root-related pain. Pain Pract 2:98-121, 2002

42. Subramanian ML, Abedi G, Ness S, Ahmed E, Fenberg M, Daly MK, Houranieh A, Feinberg EB: Bevacizumab vs ranibizumab for age-related macular degeneration: 1-year outcomes of a prospective, double-masked randomised clinical trial. Eye (Lond) 24(11):1708-1715, 2010

43. Tran J, Master Z, Yu JL, Rak J, Dumont DJ, Kerbel RS: A role for surviving in chemoresistance of endothelial cells mediated by VEGF. Proc Natl Acad Sci USA 99(7):4349-4354, 2002

44. Triantafylla M, Massa HF, Dardabounis D, Gatzioufas Z, Kozobolis V, loannakis K, Perente I, Panos GD: Ranibizumab for the treatment of degenerative ocular conditions. Clin Ophthalmol 8: 1187-1198, 2014

45. Yamagami T, Matsui $H$, Tsuji $H$, Ichimura K, Sano A: Effects of laminectomy and retained extradural foreign body on cauda equina adhesion. Spine 18(13):1774-1781, 1993

46. Yang JC, Haworth L, Sherry RM, Hwu P, Schwartzentruber DJ, Topalian SL, Steinberg SM, Chen HX, Rosenberg SA: A randomized trial of bevacizumab, an anti-vascular endothelial growth factor antibody, for metastatic renal cancer. $\mathrm{N}$ Engl $\mathrm{J}$ Med 349:427-434, 2003 